
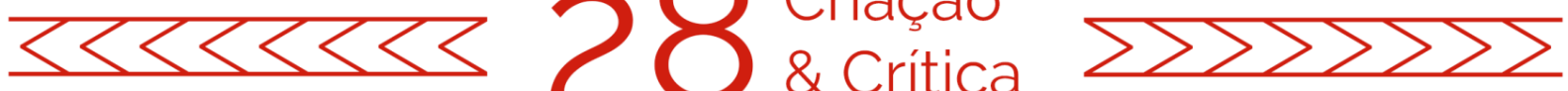

\title{
LITERATURA: O POTENCIAL HUMANIZADOR \\ DA MAIS SOLITÁRIA DAS ARTES
}

Gabriela Richinitti ${ }^{1}$

Resumo: O ensaio examina os desdobramentos éticos, estéticos e sociais da literatura contemporânea, concebida em um mundo imagético e turbulento, que enfrenta a dissolução das crenças estabelecidas na modernidade e convive com ideias radicalmente polarizadas. Nesse ambiente, a escrita e a leitura se colocam como atos humanizadores, na medida em que promovem movimentos empáticos para a constituição e a compreensão das personagens, possibilitando diferentes formas de conexões intersubjetivas. Tida como a mais solitária das artes, a literatura é capaz de aproximar pessoas, ampliando suas relações interpessoais e rompendo o individualismo que caracteriza a pós-modernidade. Nos livros, o leitor se depara com modelos éticos do mundo, que permitem a criação sentidos e o enfrentamento das questões que atravessam a vida e as relações humanas. Do escritor, por sua vez, exige-se sensibilidade altruística para captar as narrativas do mundo real e das pessoas que o habitam.

PALAVRAS-CHAVE: Literatura contemporânea; Ética; Intersubjetividade; Leitura; Escrita.

\section{LITERATURE: THE HUMANIZING POTENTIAL OF THE MOST SOLITARY OF THE ARTS}

ABSTRACT: The essay examines the ethical, aesthetic and social developments of contemporary literature, conceived in a turbulent and imagetic world, which faces the dissolution of beliefs established in modernity and coexists with radically polarized ideas. In this context, writing and reading stand as humanizing acts, as they promote empathic movements for the constitution and understanding of the characters, enabling different forms of intersubjective connections. Considered the most solitary of the arts, literature is capable of bringing people together, improving their interpersonal relationships and breaking the individualism that characterizes postmodernity. In the books, the reader is faced with ethical models of the world, which allow the creation of meanings and the confrontation of the issues that cross human life and relationships. The writer, in its turn, is required to be altruistically sensitive to grasp the narratives of the real world and the people who inhabit it.

KEYWORDS: Contemporary literature; Ethic; Intersubjectivity; Reading; Writing.

\section{Introdução}

Quem hoje escreve ficção o faz em meio à túrbida realidade do século $\mathrm{XXI}$, sobre esse limbo aberto entre a ausência de um projeto estável de futuro e a ruína das crenças disseminadas na modernidade. Para representar o vórtice de experiências do Ocidente tecnocapitalista, muitos escritores têm buscado narrar o ritmo imagético das metrópoles e

\footnotetext{
${ }_{1}^{1}$ Doutoranda no Programa de Pós-Graduação em Letras da Pontifícia Universidade Católica do Rio Grande do Sul (PUCRS), área de concentração em Escrita Criativa (bolsista CNPq). Mestra em Letras - Escrita Criativa pela PUCRS. E-mail: grichinitti@gmail.com
} 

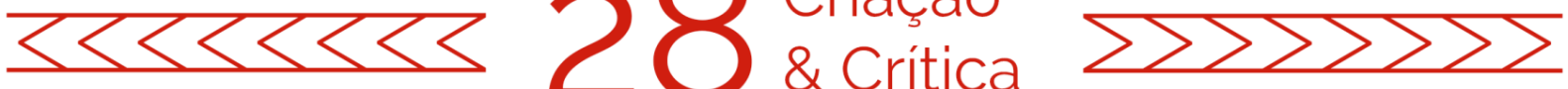

a arritmia em que se movem seus habitantes através da desagregação das formas tradicionais da narrativa, rompendo com a linearidade, perturbando as estruturas do texto ou ainda trazendo à prosa recursos poéticos. São respostas parciais à inquietude que decorre da proliferação de medos, frustrações e desejos que se estilhaçam em possibilidades consumíveis de prazer imediato, retratos da solidão e da desconexão dos sujeitos. Ante a ruína do paradigma moderno, tateamos às escuras nesse terreno movediço a que chamamos pós-modernidade.

Em meio ao vórtice de imagens e discursos que disseminam verdades concorrentes, a literatura procura captar o espírito plúrimo de nossa época e dos sujeitos que por ela transitam. Seja para "inscrever, exatamente, memórias no mundo que sofre da extraordinária facilidade para esquecer o que não convém lembrar" (SOUZA, 2018, p. 9) ou para propor uma leitura e um modo de estancar essa realidade hemorrágica, escrever significa persistir na esperança. O escritor tenta compreender as razões que subjazem ao arbítrio aparente e escava a riqueza de sonhos que se deixaram soterrar sob programas homogeneizantes de felicidade e sucesso. No texto Escrever como ato ético, Ricardo Timm de Souza identifica, no ato de escrever, o definitivo ato de decidir - também um ato de loucura. A respeito da escrita que se produz em um universo "da banalização e da mediania", do "culto do barato", discorre o autor:

Quem escreve com vigor e pertinácia, perseverança e ansiedade, sinceridade e energia concentrada, cuidado extremo e extrema coragem, despossuindo-se no ato de se entregar, pela escrita, à imponderabilidade de um destino aberto, esse sulca pequenas mensagens de estranha esperança, que encerra então delicadamente nas garrafas que serão lançadas no mar da incerteza. A verdadeira escrita é o mais pungente testemunho de deflação narcísica; não pode se dar onde o estilo é conspurcado pela menor das manchas de puro subjetivismo. A capacidade de suportar o externo que se coagula em obra escrita é rara (...) (SOUZA, 2018, p. 55).

Pode-se escrever, é claro, para um mundo à beira da morte inevitável, como também se escreve a um amante que, na alienação da velhice, já não percebe o sentido das palavras. Não cabe, aqui, inquirir a razão íntima de cada escritor, mas defender a hipótese de uma escrita lúcida em tempos de insânia e obscuridade, em que tudo o que um dia nos pareceu moralmente seguro estremece diante da impossibilidade de consenso. De outra parte, pretende-se reafirmar o poder da obra de arte no engendramento de um modelo de realidade que nos oriente no fluxo tumultuado do tempo e aproxime os seres humanos uns dos outros, fortalecendo os nós que sustentam - ou, antes, buscam sustentar - a coesão da sociedade.

Assim, o presente ensaio enfocará alguns desdobramentos da literatura e do próprio ato de escrever neste século conturbado, que oscila entre verdades contestadas e polarizações radicais, entre construções de imaginários coletivos e o culto ao indivíduo. Para captar o conteúdo humano do sujeito contemporâneo, o escritor precisa ser capaz de situar-se em sua própria experiência de mundo para, depois, abrir-se à apreensão do 

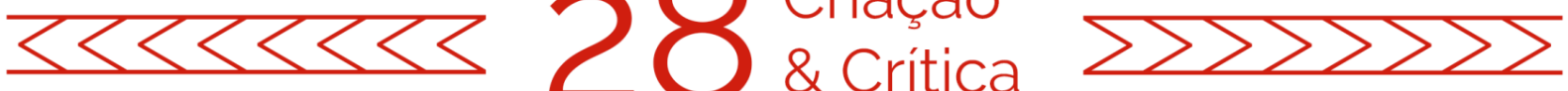

outro, em um movimento de alteridade que pode revelar-se brusco ou tormentoso, sobretudo em um sistema que promove a neutralização das diferenças - ou, antes, o repúdio a tudo o que escapa a parâmetros culturalmente legitimados. Catalisando essas reflexões, colocaremos a personagem do romance no centro dos dilemas éticos e estéticos que permeiam a literatura produzida nessa zona de turbulência simultaneamente refratária a esquemas representativos e carente de intérpretes hábeis.

Pensaremos, primeiro, no que há de verdadeiramente inter-humano e social na literatura - desde o processo criativo até suas formas de disseminação. Tomada como a mais solitária das artes, tanto no que tange à escrita quanto ao ato de leitura, ela guarda um considerável potencial de aproximação entre os indivíduos, tornando-os mais empáticos e mais capazes de compreender as razões e atitudes que constituem o outro. Analisaremos, ainda, as relações entre escritor e leitor, bem como as manifestações literárias que têm como palco o espaço urbano.

A seção seguinte se deterá sobre a escrita de autoficção, relacionando-a ao fenômeno das redes sociais e ao individualismo da contemporaneidade, abordando aspectos éticos e problematizações que permeiam o gênero. No tópico seguinte, o foco recairá sobre a criação da personagem eminentemente ficcional, analisando em que medida se trata de um exercício de alteridade em que o escritor é levado a acessar realidades diversas da sua. Por fim, a leitura será trabalhada em seu poder humanizador, considerando que a obra literária entrega ao leitor um modelo reduzido do mundo e das pessoas que o habitam, permitindo compreendê-lo e assimilá-lo. Assim, o ensaio versará sobre aspectos da literatura e da escrita em sua relação com os fenômenos da contemporaneidade, com as experiências subjetivas, com as relações interpessoais e com os modos de enfrentamento da vida humana.

\section{A mais solitária das artes e seus aspectos inter-humanos}

A literatura é a mais solitária das artes. O trabalho que a produz é reservado, silencioso, introspectivo; a única repercussão física evidente ocorre nas mãos que redigem ou digitam, e nada além. Os esforços mentais, embora exaustivos, não se mostram. Assim como o pintor, o escritor confronta solitariamente seu suporte - a tela, a folha em branco -, batalhando contra os problemas que surgem e aplicando reparos constantes às imperfeições. Embora a verve criativa tenha algo de indômita, o bom artista é também aquele que se atém às fissuras de uma lógica que ele próprio concebeu, respondendo aos imperativos de um sistema criado. Alguns entregam a peça ao público para livrar-se dela, diante de seu eterno estado de incompletude. Mesmo uma obra finalizada pertence a um processo inacabado, em que cada forma representa um objeto acabado em potencial (SALLES, 1998, p. 78).

Diferentemente da pintura, a obra escrita não é feita para ser exposta em ambientes por onde circularão dezenas, centenas ou milhares de pessoas. Os museus de livros chamam-se bibliotecas e dentro deles se exige silêncio e parcas interações. $O$ ato 

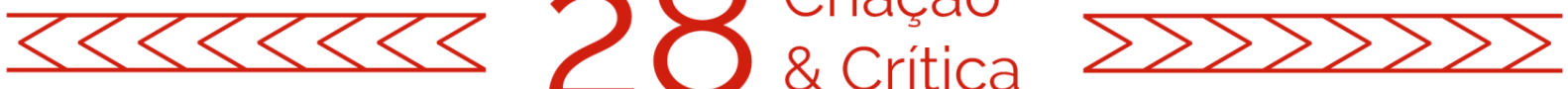

da leitura é, tanto quanto o da escrita, solitário. Pode-se partilhar ideias a respeito de um romance lido, mas essa partilha é sempre diferida; o instante vivo da primeira leitura é de isolamento mental, pois dele depende a apreensão do sentido pleno das palavras.

Há, é claro, os momentos de exceção em que a literatura se torna o catalisador de eventos sociais. Os lançamentos precedem a leitura efetiva. Os saraus, por sua vez, não a substituem: podemos desfrutar do prazer de ouvir um conto na voz de outro, mas, se nos limitarmos a isso, perderemos uma parte muito significativa do objeto artístico. Textos narrativos e sobretudo poemas se fazem, também, de suas formas. Além disso, assim como a escrita, o ato de ler não é linear: implica correções e retomadas, vale-se da disponibilidade física das palavras constantemente. A efemeridade do som impossibilita as idas e vindas que a apreensão mais profunda do texto requer. Dessa forma, a experiência social da literatura é incapaz de suplantar seu consumo solitário, diferentemente do que ocorre com outras artes. Um filme, por exemplo, pode ser assistido na sala de cinema ou em casa, sem que isso implique uma perda tão substancial do objeto; embora as vivências sejam distintas, o contato direto do espectador com a obra cinematográfica persiste em ambas. Ademais, bons leitores nem sempre são frequentadores assíduos de saraus, ao passo que é raro encontrar um apreciador da sétima arte que jamais compartilhe sessões com outras pessoas, seja nas salas de cinema ou no ambiente doméstico.

Qual seria, portanto, o aspecto marcadamente inter-humano da literatura? Em que medida ela promove encontros, aproxima os sujeitos e desenvolve a alteridade? De que modo estabelece vínculos e reforça as relações entre as pessoas?

Em primeiro lugar, no que tange ao ofício do escritor, o isolamento físico não implica o alheamento absoluto. Como salienta Cecilia Almeida Sales, a solidão do artista não significa uma recusa ao mundo. "Escrever, para Cesare Pavese (1988), contém duas alegrias: falar sozinho e falar a uma multidão" (SALLES, 1998, p. 81). O escritor deve ser sensível às questões humanas para transformá-las artisticamente, pois sua capacidade de perceber o outro - suas angústias e expectativas, seus modos de agir e razões silenciosas - é o que lhe permite dar substância às personagens. Disso falaremos mais detidamente na quarta seção deste artigo.

Há, ainda, outra espécie de encontro que a escrita promove: aquele estabelecido entre o escritor e o leitor hipotético, para quem se destina a obra em vias de produção. Esse destinatário é projetado ao longo de todo o processo criativo; é pensando nele que o autor escreve, intuindo sua percepção das personagens, bem como as dúvidas e os impasses morais que lhe surgirão no avanço da narrativa. É por causa dele que se busca um certo grau de clareza nas construções frasais, que não devem ficar demasiadamente cifradas. Quem escreve apenas para si não precisa se preocupar com eventuais obscuridades; o escritor, por sua vez, precisa estabelecer a medida de compreensão do leitor para o qual se dirige. Por isso, escreve sempre na companhia de um interlocutor suposto e invisível, que, ao final do processo, provavelmente se materializará na figura do "leitor beta" - em geral, uma pessoa 

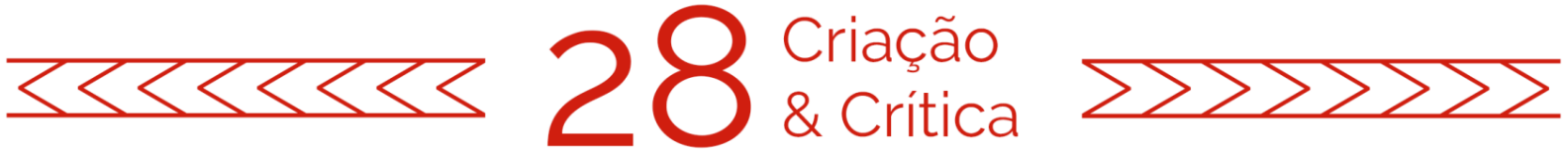

próxima a quem se confia o original de um livro para que faça suas observações. Produzir ficção exige, portanto, um trabalho radical de intuir o outro.

O escritor está o tempo inteiro dialogando com o leitor hipotético, desde a escolha da linguagem - que será diferente se estiver trabalhando em uma história infantil, por exemplo - até os jogos de claro-escuro que faz. Para prender sua atenção, escolhe-se mostrar ou esconder determinados elementos no desenrolar do enredo. A relação da obra com o leitor é tão importante que serviu de tema ao romance Se um viajante numa noite de inverno, publicado em 1979 por Italo Calvino. Já o primeiro capítulo do livro se comunica diretamente com o leitor, inclusive lhe dando instruções para ingressar no universo da obra:

Você vai começar a ler o novo romance de Italo Calvino, Se um viajante numa noite de inverno. Relaxe. Concentre-se. Afaste todos os outros pensamentos. Deixe que o mundo a sua volta se dissolva no indefinido. É melhor fechar a porta; do outro lado há sempre um televisor ligado. Diga logo aos outros: "Não, não quero ver televisão!". Se não ouvirem, levante a voz: "Estou lendo! Não quero ser perturbado!". Com todo aquele barulho, talvez ainda não o tenham ouvido; fale mais alto, grite: "Estou começando a ler o novo romance de Italo Calvino!". Se preferir, não diga nada; tomara que o deixem em paz (CALVINO, 2002, p. 11).

Por óbvio, Italo Calvino não sabia por quem seria lido, muito menos em que momento. As circunstâncias que atribui ao leitor hipotético foram supostas para gerar uma interlocução que, nesse caso, aparece de maneira explícita, mas que, em maior ou menor medida, atravessa qualquer processo criativo - assumindo que exista, na semente de cada obra, o intuito de torná-la pública. O próprio devir da arte consiste em um movimento de aproximação entre os homens.

Raramente enunciada, essa complexa interação entre escritor e leitor é fundamental à própria existência da literatura. No paradigmático ensaio $A$ morte do autor, Roland Barthes procurou afastar a figura do autor, livrando o texto de um pretenso significado último. Postulando pela derrocada do império do autor, deslocou para a leitura toda a importância ao afirmar que "há, entretanto, alguém que ouve cada palavra na sua duplicidade, e ouve mais, pode-se dizer, a própria surdez das personagens que falam diante dele: esse alguém é precisamente o leitor (ou, no caso, o ouvinte)" (BARTHES, 1984, p. 70). Embora no ato da leitura se fale no distanciamento dessa entidade onipotente, a prática do escritor exige uma espécie de diálogo imaginário ininterrupto com o destinatário - que, mais tarde, poderá romper efetivamente com a figura do autor, assumindo que o texto represente esse "espaço de dimensões múltiplas, onde se casam e se contestam escrituras variadas, das quais nenhuma é original" (BARTHES, 1984, p. 68-69). Para Barthes, "o leitor é um homem sem história, sem biografia, sem psicologia; ele é apenas esse alguém que mantém reunidos em um único campo todos os traços de que é constituído o escrito" (BARTHES, 1984, p. 70). Ao afirmar finalmente que "o nascimento do leitor deve pagar-se com a morte do Autor" (BARTHES, 1984, p. 70), torna 

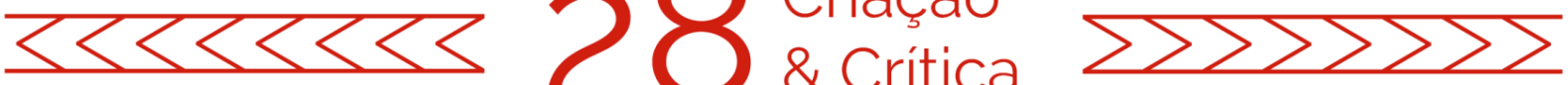

ainda mais dramática essa relação: é como se um se sacrificasse pelo outro - ou, ao menos, pelo texto.

Procuramos tratar, até aqui, dos aspectos inter-humanos inerentes à literatura de modo geral, sem levar em consideração as particularidades de cada desdobramento possível da arte literária. Há, contudo, um formato que se destaca por sua expressividade e por seu caráter eminentemente social, merecendo um tratamento à parte neste ensaio: trata-se do poetry slam uma forma poética altamente performativa, de marcado viés comunitário e político. A reunião do público em torno dos poetas e a apreciação das apresentações por um corpo democrático de jurados é parte essencial dessa manifestação artística, que se configura como uma espécie de batalha de poesia oral:

O poetry slam é uma batalha de poesia falada, cujas cinco regras principais, apesar de variarem de lugar para lugar, tendem a permanecer relativamente as mesmas: os competidores têm três minutos para apresentar sua poesia autoral e inédita naquele slam, sem o auxílio de adereços de cena ou acompanhamento musical. As poesias são julgadas pelo público e pelos jurados imediatamente após sua leitura/recitação/acontecimento, em uma escala de zero a dez. O júri é constituído por pessoas escolhidas aleatoriamente na plateia. Das notas dos cinco jurados, a maior e a menor são descartadas, compondo uma nota final que varia entre zero e trinta pontos. O poeta geralmente passa por três rodadas, tendo que apresentar três poesias vencedoras antes de se tornar o campeão da noite (FREITAS, 2020, p. 2).

Tendo o exercício da cidadania como motriz dos eventos, o poetry slam promove o uso do corpo e da voz, a veiculação poética de insurgências políticas, o reforço dos vínculos sociais e a integração dos sujeitos com a cidade. Operando no interstício entre a oralidade, a escrita e a performance, "tensiona ainda mais os limites entre literatura e música, poesia e vida, arte e ativismo - limites já complicados por outras manifestações da cultura hip-hop", (FREITAS, 2020, p. 2). Ao combinar elementos de diversas formas artísticas, imbrica a literatura à expressão corporal e à fruição coletiva da palavra, fazendo-a ultrapassar de vez as fronteiras da introspecção para promover a tomada poética de lugares não-convencionais. Desde sua origem, o poetry slam adotou uma política de portas abertas, permitindo que todos os interessados participem da batalha e qualificando qualquer um do público para julgar. Nesse sentido, Susan Somers-Willet contrapõe os ambientes tradicionalmente reservados à leitura ao território radicalmente democrático dos slams, onde impera a ideia de que a poesia pode ser acessada por qualquer pessoa que se disponha a escutá-la:

Tal ênfase no público como crítico se distingue dos eventos de leitura de poesia mais tradicionais, que celebram ou reverenciam autores previamente classificados como dignos de valor por autoridades literárias. $O$ poetry slam foi fundado sobre as premissas de que o poeta deve convencer o público a ouvi-lo, que qualquer um pode julgar uma competição e que a competição deve ser aberta a todas as pessoas e 

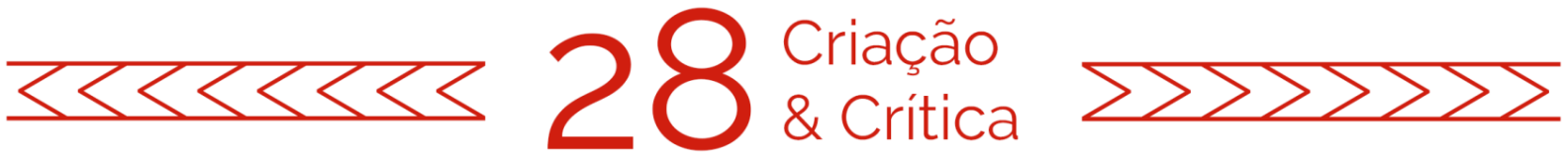

todas as formas de poesia. Slam poetry é verso que, pelo menos em teoria, pode ser acessado por qualquer um e cujo valor qualquer um pode determinar. A acessibilidade da slam poetry é facilitada e talvez exigida pela linguagem da performance, que se submete ao tempo e o espaço, e talvez mais importante - à atenção da plateia. Em competições de slam nacionalmente certificadas, os poetas têm uma janela de no máximo três minutos, que, como o poeta e showman Bob Holman aponta, é exatamente a duração de uma canção popular (SOMERS-WILLET, 2009, citada por FREITAS, 2020, p. 2-3).

Em Performance, recepção e leitura, Paul Zumthor observa que, em face do avanço impositivo da sociedade de consumo, resiste-se na poesia, nas formas de vida social e de expressão corporal dinamizadas pela voz, ainda que essa resistência não implique necessariamente um intuito de recusa ou contestação. Nesse sentido, estaríamos "no limiar de uma nova era da oralidade, muito diferente do que foi a oralidade tradicional; no seio de uma cultura na qual a voz, em sua qualidade de emanação do corpo, é um motor essencial da energia coletiva" (ZUMTHOR, 2014, p. 62-62). Sob esse prisma, a reintrodução da voz, do corpo e do convívio social à poesia, conforme empreendida pelo poetry slam, revigora a literatura enquanto instrumento de resistência, na contracorrente das forças alienantes da civilização tecnológica. Em oposição à leitura solitária - o grau performático mais fraco -, o slam se insere na categoria que Zumthor define como "performance com audição acompanhada de uma visão global da situação de enunciação", ou seja, um tipo de performance completa (ZUMTHOR, 2014, p. 69). Como salienta o autor, a performance não é um simples meio de comunicação; ao transmitir aquilo que conhece, transforma o conhecimento (ZUMTHOR, 2014). A experiência performática da poesia, portanto, não deve ser vista como suplementar à leitura solitária e silenciosa, mas uma manifestação cultural diversa, capaz de reaproximar a literatura da oralidade, da corporeidade e, consequentemente, do ambiente coletivo.

\section{Fronteiras borradas entre realidade e narrativa ficcional: das redes sociais à autoficção}

Antes de adentrarmos nas questões éticas e intersubjetivas que permeiam a literatura ficcional, enfocaremos dois temas que não podem restar à margem das discussões sobre as formas narrativas no século XXI e suas relações com a sociedade e o indivíduo: as redes sociais e a autoficção. Ambas serão estudadas, aqui, como possíveis desdobramentos de uma sociedade fundada no culto da imagem, no individualismo e no narcisismo que caracterizam o ambiente pós-moderno:

Instaura-se um novo estágio do individualismo: o narcisismo designa o surgimento de um perfil inédito do indivíduo em suas relações consigo próprio e com o seu corpo, com os outros, com o mundo e o tempo, no momento em que o «capitalismo» autoritário dá lugar a um capitalismo hedonista e permissivo. A idade de ouro do individualismo, concorrencial 

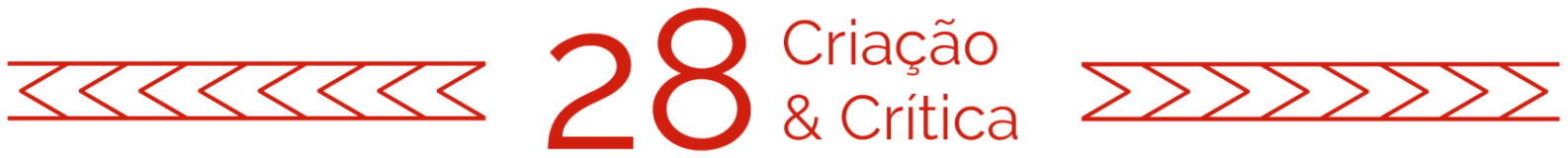

ao nível económico, sentimental ao nível doméstico, revolucionário ao nível político e artístico, chega ao fim, desdobra-se um individualismo puro, livre dos últimos valores sociais e morais que coexistiam ainda com o glorioso reinado do homo aeconomicus, da família, da revolução e da arte; emancipada de todos os enquadramentos transcendentes, a própria esfera privada muda de sentido, exposta como está apenas aos desejos mutáveis dos indivíduos. Se a modernidade se identifica com o empreendedorismo, com a esperança futurista, é claro que, por sua indiferença histórica, o narcisismo inaugura a pós-modernidade, a última fase do homo aequalis (LIPOVETSKY, 1989). ${ }^{2}$

Nas redes sociais, criam-se simulacros identitários capazes de estabelecer vínculos com outros e de produzir narrativas autorais através de fotografias, textos, opiniões e compartilhamento de conteúdo. As selfies denotam uma maneira narcisista de autoexposição - muitas vezes, funcionam como registros assíduos das experiências individuais. Enquanto 0 individualismo capitalista se exacerba nesses modos autocentrados de comunicação, abre-se ao sujeito a possibilidade de construir uma versão da própria história - em outras palavras, a virtualidade é um espaço potencialmente criativo.

Em sua célebre aula de 1977, Roland Barthes preleciona a natureza irrepresentável do real, passível apenas de demonstração, uma vez que a ordem pluridimensional da realidade não pode ser conciliada com a ordem unidimensional da linguagem, rompendo qualquer paralelo imediato entre ambas (BARTHES, 1980). Assim, pode-se dizer que, no intuito de demonstrar a realidade através da palavra e da imagem, a pessoa faz escolhas narrativas, tornando-se, no âmbito das redes sociais, autora de si afastando-se, em maior ou menor escala, do mero registro dos fatos para explorar a amplitude exponencial da invenção.

A coincidência entre a autoexposição veiculada nas redes sociais e a proliferação de obras de autoficção permite-nos supor que exista algum fator comum entre os fenômenos. A rigor, a autoficção não é um gênero novo, mas a variante moderna de um gênero antigo, remontando a autores como Montaigne, Rousseau e Thomas de Quincey, cujas obras foram escritas nos séculos XVI, XVIII e XIX, respectivamente (PERRONE-MOISÉS, 2016). Sintomático, portanto, é o resgate profícuo dessa tradição nos dias de hoje.

A autoficção tem como elemento inafastável a identidade explícita do nome do autor com o nome da personagem que narra a história. Embora a veracidade dos eventos narrados possa ser discutida, o aporte de realidade para o interior do universo da ficção faz emergirem problemas de ordem ética, na medida em que frequentemente são expostas pessoas do círculo afetivo do autor. Se, nas redes sociais, o narcisismo se alimenta da cultura voyeurística, o arranjo se repete na literatura de autoficção, na qual o autor apresenta uma parcela de sua vida privada para um público ávido por adentrar as

2 Tradução realizada pela autora deste ensaio a partir da edição francesa de L'Ėre du vide: Essais sur l'individualisme contemporain, de Gilles Lipovetsky. 

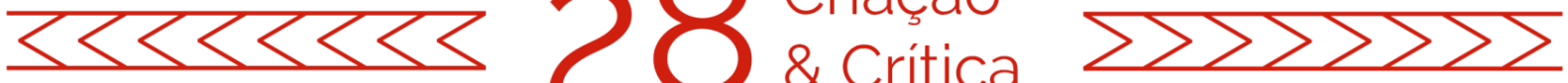

esferas mais íntimas dos indivíduos. Assim, a liberdade artística pode entrar em confronto direto com o direito à privacidade. Cabe lembrar que, na Constituição Federal brasileira, o art. 5, inciso X, dispõe que "são invioláveis a intimidade, a vida privada, a honra e a imagem das pessoas, assegurado o direito à indenização pelo dano material ou moral decorrente de sua violação" (BRASIL, 1988). O mesmo art. 5, contudo, em seu inciso IX, determina que "é livre a expressão da atividade intelectual, artística, científica e de comunicação, independentemente de censura ou licença" (BRASIL, 1988). Nesse sentido, a autoficção pode originar problemas éticos, culminando até mesmo em um conflito entre normas constitucionais.

No Brasil e no mundo, obras desse gênero já foram levadas aos tribunais por pessoas que se sentiram expostas e aviltadas pela transposição ficcional de suas vidas privadas. Na França, em 2013, a escritora Christine Angot e sua editora, Flammarion, foram condenadas a pagar 40 mil euros em função de episódios narrados em seu livro Les Petits. No Brasil, abriu-se um inquérito contra o escritor paulistano Ricardo Lísias para investigar a falsificação e o uso de documento público falso; o motivo foi a publicação do folhetim digital intitulado Delegado Tobias. Não é incomum que, ao borrar as fronteiras entre a realidade e a ficção, o autor dê causa a discussões éticas e jurídicas, sem falar no impacto que esse gênero literário pode acarretar às vidas de todos aqueles que, mesmo sem desejar, veem-se transformados em personagens.

Muitos autores experientes sustentam que as boas personagens não são cópias fiéis de pessoas da vida real - e é melhor que não sejam, "a menos que você queira ser processado ou levar um tiro ao sair para pegar a correspondência em uma bela manhã”, como afirma o mestre do terror, Stephen King, em seu livro Sobre a escrita (KING, 2015, p. 162). Ainda que se admita que qualquer narrativa sempre conterá uma carga ficcional, a autoficção carrega, em sua essência, uma maior expectativa de aderência a eventos e pessoas reais; assim, é legítimo presumir que o leitor chegará ao texto esperando encontrar ali alguma medida de verdade, ainda que colorida pelo prisma da voz que narra a história - sendo essa voz chancelada, por sua vez, pela presença do nome do autor. Parece um artifício desonesto isentar a autoficção de seu poder de construir uma versão eficaz da verdade, resguardando-a dos problemas éticos que lhe são inerentes.

Além dos impulsos voyeurísticos de nossa sociedade, podemos supor outra causa ao sucesso e à abrangência da autoficção na literatura do século XXI: a facilidade que o sujeito contemporâneo tem de narrar a si próprio, em contraposição ao tormentoso exercício da alteridade dentro de um modelo econômico e de um sistema educacional que preconizam o individualismo e a competição. Enquanto propulsores do consumo, a vaidade e o narcisismo também se desdobram em manifestações artísticas, como é o caso da escrita de autoficção, na qual o protagonismo cabe ao próprio autor, que focaliza passagens de sua história e personagens de seu convívio.

Para criar uma personagem que rompa com sua fisionomia e visão de mundo, o escritor precisa observar e compreender aqueles que o cercam. Isso não significa replicar pessoas já existentes, mas captar as razões intrínsecas que levam diferentes mulheres e 

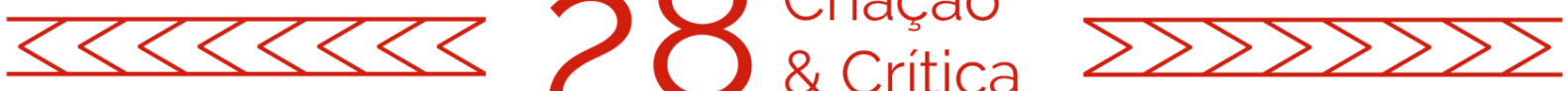

homens a pensar e agir da maneira como agem e pensam, gostemos ou não. Esse movimento não é simples, porque requer de nós mais do que a empatia passiva, que nos faz aceitar o outro a uma distância segura; é preciso encontrá-lo em suas ambiguidades, incongruências, verdades hostis e qualidades raras. Nesse sentido, a definição de outro se aproxima da presença não antevista, que nos chega inesperadamente para romper a ilusória onipotência do eu, como escreve Ricardo Timm de Souza (2018, p. 61):

"Outro" é o que nunca antes esteve presente ao nosso encontro, ou seja, o que inelutavelmente rompe traumaticamente meu solipsismo, na medida em que chega de fora, fora do âmbito dilatado de meu poder intelectual, de meu narcisismo e de sua tendência de considerá-lo - a Outro - nada mais do que uma representação lógica ou desdobramento inferencial do meu intelecto.

No extremo, a escrita de si coloca o indivíduo no foco dos acontecimentos, abordando o outro como um desdobramento do seu intelecto - submetendo-o às forças perceptivas do eu, o que se torna um problema ético quando falamos de pessoas supostamente reais. É claro que o escritor sempre deixará rastros de sua visão de mundo e de sua experiência pessoal no texto; ocorre que, na autoficção, há uma aparência de verdade - chancelada por nomes e fatos - veiculada através de uma narrativa que, embora envolva outras partes, raramente lhes dá direito a um contraditório qualificado.

Por fim, não se trata de estabelecer um juízo negativo acerca da autoficção, mas de percebê-la à luz de sua época, reconhecendo as questões éticas envolvidas. Embora o real seja, como afirmou Barthes, irrepresentável, a representação tem o poder de influir sobre a realidade - daí a força da literatura e, mais amplamente, da arte.

\section{A personagem de ficção: a escrita como um movimento de empatia}

No tópico anterior, trabalhamos algumas implicações éticas atreladas à autoficção, em que a figura da personagem confunde-se com a identidade do próprio escritor. Discorremos, também, sobre possíveis razões que subjazem ao sucesso do gênero nos dias atuais. Repartiu-se o estudo dessa maneira em respeito às peculiaridades que a escrita autoficcional guarda em relação à literatura que se assume, desde o princípio, como um produto da imaginação do autor, com personagens e situações livremente inventadas. É sobre a literatura de ficção - e, mais especificamente, sobre a personagem ficcional - que este capítulo versará.

A ficção não é um compromisso com a mentira. É, antes, uma liberdade em face da verdade. Pode-se averiguar em que proporção a obra fictícia guarda semelhanças com o mundo real; isso, contudo, não tem maior relevância artística, desde que a narrativa nos convença de sua realidade singular através da lógica que lhe é intrínseca. Não buscamos, na ficção, a verdade, mas a verossimilhança. Um universo completamente fantasioso, repleto de criaturas fantásticas, pode ser verossímil dentro de suas próprias regras. Nada disso implica dizer que a ficção não extrai seus recursos 

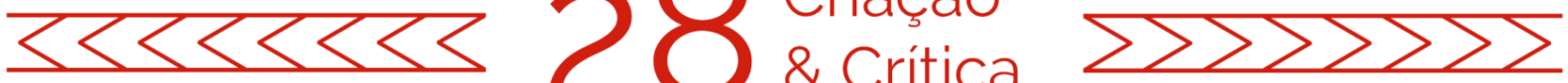

da realidade, pois é dentro dela que a própria literatura existe, sendo a partir de seus mecanismos que se engendram as narrativas.

Boas histórias estão, quase sempre, atreladas a grandes personagens. Mas, afinal, o que vem a ser a personagem ${ }^{3}$, "esse ser de mentira, homo fictus, persona, simulacro, máscara, sombra, outro" (PALLOTTINI, 1989, p. 5). Em seu livro Dramaturgia: A construção do personagem, a dramaturga Renata Pallottini define a personagem como um ser composto a partir da realidade, que "não reúne, em todo caso, todos os traços passíveis de serem encontrados num ou em muitas pessoas, seus modelos" (PALLOTTINI, 1989, p. 5). $\mathrm{Na}$ sequência, afirma que se trata da "imitação, e portanto a recriação dos traços fundamentais de pessoa ou pessoas, traços selecionados pelo poeta segundo seus próprios critérios" (PALLOTTINI, 1989, p. 5). Vê-se que a definição de Pallottini coloca na realidade e nas pessoas reais o substrato do qual se extraem os elementos para a criação dos traços da personagem - que se torna, porém, uma entidade autônoma concebida pelo escritor. Disso se infere que grandes personagens são criadas a partir da apurada compreensão que o escritor tem do mundo real e das pessoas que o habitam.

Antes de ser um exímio leitor de ficção, o escritor precisa ser um receptivo leitor de realidades. Se decidir escrever somente sobre aquilo que domina por ocasião de sua própria vivência, é provável que seus recursos logo se esgotem e terminará repisando o próprio rastro, narrando circularmente o que lhe cerca e o que sente por ser quem é. Por isso, é tão complicado ensinar alguém a escrever. Pode-se ensinar o instrumento da língua, demonstrar os elementos da narrativa, fornecer os recursos materiais necessários para dar concretude às ideias, mas é muito difícil ensinar alguém a compreender o mundo de uma forma autônoma e original. É ainda mais difícil treinar alguém para intuir, com algum grau de razoabilidade, as diferentes razões que se contrapõem nesse mundo. Para reunir, sob a unidade da personagem, traços percebidos nas demais pessoas, o escritor coloca-se hipoteticamente no lugar de outro, passando então a depreender como esse alguém pensaria e agiria em determinadas circunstâncias. Trata-se, portanto, de um movimento essencialmente empático - de seleção, combinação e transformação das qualidades comuns e distintivas dos seres humanos.

A personagem não é, mas poderia ser; nela, o autor reúne as condições de existência de uma pessoa que, não sendo necessariamente real, é verossímil. No intuito de alcançar a verdade profunda dos seres, quem escreve deve despir-se, ao máximo, dos preconceitos e das leituras esquemáticas que circunscrevem o universo aos seus limites narcísicos. Para que aja como um deus criador, precisa reconhecer seus limites perceptivos e a autonomia de todas as narrativas individuais que precedem qualquer criação; há que ser um deus modesto, portanto.

\footnotetext{
${ }^{3}$ Há um conflito terminológico acerca do substantivo personagem. A língua portuguesa, contudo, admite os dois gêneros - a personagem ou o personagem. Neste ensaio, preferimos manter o uso clássico, a personagem.
} 

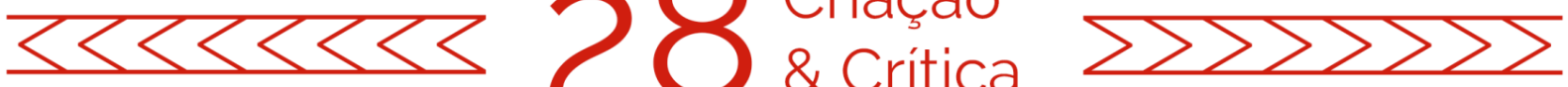

\section{A leitura é um ato humanizador}

É com a personagem - e não com a massa de eventos, fatos e descrições - que o leitor se envolve. Os acontecimentos e reviravoltas da história são importantes na medida em que dizem algo a respeito da personagem ou que influem sobre sua trajetória. Em torno dela, desdobram-se os eventos e, em função dela, avançamos na obra: queremos saber o que sucederá em seu universo, em que medida sairá transformada da narrativa. Não raro, lembramo-nos com viveza da personagem de um livro que lemos, embora tenhamos esquecido a sequência dos fatos que formaram a história. Sobre a posição central da personagem na narrativa, escreve Luiz Antonio de Assis Brasil:

A narrativa deve convencer o leitor de um fato; tudo o que ali está é porque o personagem, pelo simples fato de existir, faz com que as coisas aconteçam. Não, o personagem não tem poderes mágicos ou de superherói. No entanto, é como se atraísse os eventos narrados. Ou seja, os eventos de uma história estão enraizados nele, inclusive os fatos incontroláveis, como um raio que destrói uma casa ou a morte de um potentado na China, para pegarmos a ideia de Eça de Queirós na novela $O$ mandarim (1880). Soa estranho, não? Mais parece um ensinamento esotérico. Mas não é (BRASIL, 2019, p. 36).

Diante do valor que se dá a essa entidade personificada, não é exagero afirmar que $o$ ato da leitura também se funda num exercício de empatia, promovendo a inserção do leitor na realidade e nas razões de um outro, causando-lhe uma preocupação controlada com o destino dessa figura que poderia ser alguém - e parece, nos melhores casos, mais real do que a realidade que se dá na superfície do cotidiano, dessubstanciada pelo artifício das aparências e pelos procedimentos de uma sociedade homogeneizante. A leitura é, por excelência, um ato humanizador, que nos alcança a experiência do outro.

Dentro de um bom livro, cabe o mundo - um modelo reduzido do mundo, considerando que a realidade opera em uma escala grande demais para que alguém possa enxergá-la de cima e compreender de que maneira seus cenários e habitantes se relacionam e interferem uns nos outros. Em O último leitor, Ricardo Piglia diz que a obra de arte é "uma forma sintética do universo, um microcosmo que reproduz a especificidade do mundo" (PIGLIA, 2006, p. 13). Esse modelo representativo abre-se à leitura solitária, permitindo que o olhar do sujeito se estenda sobre ele, demorando-se em suas nuances, singularidades, acontecimentos triviais e rupturas. A leitura não é um ato meramente decodificador, mas contemplativo: cada pessoa que lê - e em cada momento que lê - cria sentidos e conexões entre os elementos desse cosmo de representação, no centro do qual se encontra a personagem, que é, em última instância, o outro.

O livro é um mapa e um mapa é "uma síntese da realidade, um espelho que nos guia na confusão da vida" (PIGLIA, 2006, p. 14). Quem lê, treina para viver. No íntimo do leitor ideal, que se entrega inteiramente ao universo representado, desaparece a própria 

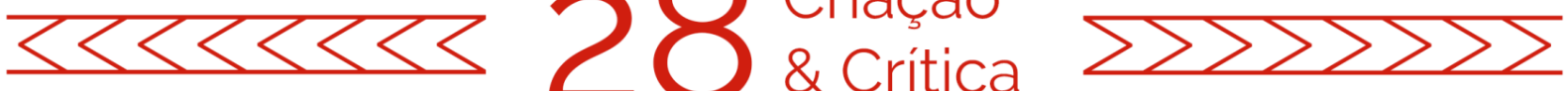

dicotomia entre a realidade e a ficção; nesse limite, o leitor vive, enriquecendo seu tempo de existir com experiências que não teria dentro da grande escala da realidade.

Ricardo Piglia retoma uma cena da vida do revolucionário Ernesto "Che" Guevara para mostrar a influência da literatura nas condutas e escolhas éticas do sujeito. Conta que o guerrilheiro, julgando-se diante da morte em razão de ferimentos graves, lembra-se do final de um conto de Jack London, chamado To Build a Fire, no qual a personagem concebe um modo digno de morrer. Guevara "encontra numa cena lida um modelo ético, um modelo de conduta, a forma pura da experiência” (PIGLIA, 2006, p. 100); na solidão da leitura, atormentado diante da proximidade da morte, modela sua realidade de acordo com o sentido que extrai do conto de Jack London. Citando Between History and Literature, de Lionel Gossman, Piglia observa que "a leitura literária substituiu o ensino religioso na construção de uma ética pessoal” (GOSSMAN, apud PIGLIA, 2006, p. 100).

Ao escrever sobre o poder da literatura em tempos e espaços de crise, Michèle Petit afirma que, em tragédias históricas, registrou-se um aumento expressivo da prática de leitura. Isso aconteceu durante a Segunda Guerra Mundial e após o 11 de setembro de 2001 (PETIT, 2009). Recorrendo aos escritos de Martine Poulain, lembra que, durante a década de 30 , em meio ao desemprego generalizado e ao pauperismo provocados pela Grande Depressão, milhares de norte-americanos acorriam às bibliotecas para buscar formas de reintegrar-se à realidade - ou mesmo para escapar um pouco a ela:

Às vezes, os desempregados buscavam na leitura uma oportunidade de se distanciar do real e de sua própria situação, esperando que ela thes levasse para 'fora do mundo'. Às vezes, esperavam o contrário, que thes mantivesse 'dentro do mundo'. A leitura de jornais e periódicos era então a mais apreciada, seja porque a leitura de 'notícias' sancionava essa necessidade de se sentir parte de uma comunidade, seja porque a consulta das ofertas de emprego assinalava mais diretamente uma busca de reintegração" (POULAIN, apud PETIT, 2009, p. 10).

Michèle Petit observa que uma crise se estabelece quando transformações profundas ou mesmo uma violência permanente e generalizada tornam ineficazes os modos de regulamentação sociais e psíquicos conhecidos. Nesse sentido, hoje o mundo inteiro seria um espaço de crise, uma vez que as vertiginosas mudanças, o aumento das desigualdades e a extensão das migrações modificaram ou fizeram desaparecer os parâmetros nos quais a vida se desenvolvia. Houve, portanto, um severo estremecimento dos modelos éticos e das certezas até então estabelecidas. Embora provoquem a perda devastadora de sentido e de referências, rupturas dessa ordem podem igualmente estimular a verve criativa das pessoas. Diante de cenários extremos de desesperança, angústia, sofrimento e desespero, a autora se questiona se a literatura pode prover forças de regeneração. Em contextos sociais em que a literatura não foi introduzida desde a mais tenra idade, recorda a importância de mediadores que plantem afetuosamente o contato com os livros. Partindo de suas pesquisas e experiências, discorre sobre programas literários estabelecidos em zonas de guerra, 

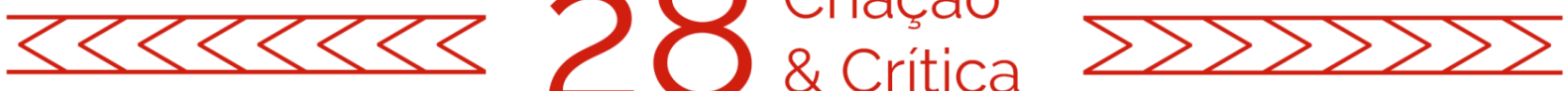

violência, recessão econômica e catástrofes naturais - iniciativas subestimadas e que pouco circulam, mas que ainda assim conseguem trazer ricos ensinamentos aos lugares onde se inserem (PETIT, 2009). Ao ressaltar a força da literatura nas zonas de instabilidade psíquica, econômica e social, atenta para o trabalho daqueles que, com afeto e dedicação, facilitam a introdução dos livros em territórios devastados pela guerra, pela catástrofe e pelo trauma - lugares onde os livros nem sempre constituem uma riqueza nativa, mas onde também conseguem dar frutos.

Michèle Petit reconhece à literatura um papel proeminente nos momentos de crise - um refúgio, mas também um modo de confrontar as adversidades. Assim como Piglia, entende que os livros oferecem alento e suporte aos indivíduos nos momentos em que lhes faltam referências, esperanças e perspectivas. À luz de reflexões e relatos de experiência, a autora conclui que a literatura transcende seu uso enquanto ferramenta pedagógica, sendo um meio de "criar ou preservar intervalos onde respirar, dar sentido à vida, sonhá-la, pensá-la”, (PETIT, 2009, p. 116), além de catalisar encontros e ideias:

A literatura, em particular, sob todas as suas formas (mitos e lendas, contos, poemas, romances, teatro, diários íntimos, histórias em quadrinhos, livros ilustrados, ensaios - desde que sejam "escritos"), fornece um suporte notável para despertar a interioridade, colocar em movimento o pensamento, relançar a atividade de simbolização, de construção de sentido, e incita trocas inéditas (PETIT, 2009, p. 116).

Retomemos as reflexões que iniciaram este ensaio: atravessamos um período de acentuada descrença quanto aos modelos éticos e epistemológicos do passado. A verdade é porosa, contestável e o sujeito contemporâneo vaga por essa teia de incertezas em busca de um sentido em que se agarrar. No Brasil, as igrejas conquistam poder na medida em que conseguem oferecer alguma verdade palpável, algum sentido às milhões de pessoas que, no mais, vagam em busca de esperança. Globalmente, a publicidade reduz ao consumo progressivo o sentido da vida no sistema capitalista. A fé e o mercado, com seus discursos éticos alienantes, oferecem uma aparência minimamente inteligível à experiência humana.

Há, contudo, uma terceira via, que pode afastar-nos da guerra, da degradação ambiental e da irracionalidade. Enquanto tantas religiões pregam o ódio, a literatura promove a alteridade. Enquanto o culto ao dinheiro motiva a desigualdade, a literatura dá voz às diferenças e reforça os aspectos comuns entre os seres humanos. Ainda que seja uma atividade solitária - em oposição ao ambiente coletivo, mas individualista das metrópoles contemporâneas -, a literatura oferece modelos éticos, mapas para compreender as razões do outro, experiências libertadoras que desafiam a circularidade dos padrões de normalidade. Ler é, em última análise, um modo eficiente de buscar um sentido autônomo para a própria vida. 

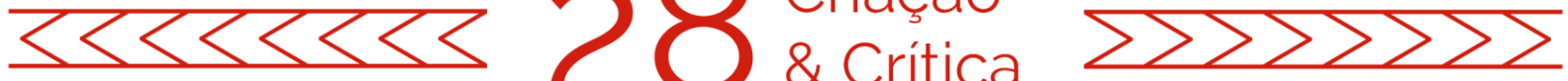

\section{Conclusão}

Do escritor exige-se uma leitura apurada do mundo, uma compreensão altruística dos outros para que, colhendo seus traços distintivos, possa reuni-los sob a unidade ficcional da personagem. A leitura, por sua vez, permite que se experiencie com autenticidade a própria vida, criando sentidos a partir dos modelos de mundo contidos nos livros e buscando amparo em meio à crise. Foi isso o que fez o leitor Ernesto "Che" Guevara ao emprestar de um conto de Jack London um modo digno de portar-se diante da iminência da morte.

Em suma, tanto a escrita quanto a leitura sensibilizam, libertam, recriam sentidos: são fugas da realidade, mas também constituem meios bravos de enfrentá-la, pois não fogem à sua aspereza e às questões mais pungentes que se colocam à experiência humana. Significam, ainda, a resistência, persistência da esperança. Afinal, quanta esperança há no ato de escrever a respeito do mundo - deste mundo, ainda que sob réplicas transformadas -, registrando-o para um futuro possível, projetando-o num horizonte em que se acredita? E quanta esperança há na prática da leitura, que nos leva a olhar para aquilo que, de outra forma, poderíamos contornar, esquecer, ignorar, vivendo à margem de qualquer sentido ou no circuito de sentidos preconcebidos pelo oportunismo daqueles que reivindicam o poder de criá-los?

A memória que a literatura inscreve no tempo não é um simples eco das circunstâncias; ela rearranja os elementos do espaço desordenado, verte luz sobre as zonas de penumbra da consciência e abre brechas de compreensão na individualidade do outro, ampliando a perspectiva de quem lê. Um universo em que a leitura e a escrita estejam extintas é um universo desumanizado, tecnocrata, descolorido, palco de irracionalidades e conflitos vazios. Enquanto manancial de modelos éticos de mundo e de estreitamento dos vínculos intersubjetivos, a literatura - nela compreendidos os atos de ler e de escrever - desafia os poderes instituídos, os pensamentos viciosos e a assepsia das relações humanas.

\section{Referências}

BARTHES, R. "A morte do autor". In: O Rumor da Língua. São Paulo: Editora Brasiliense, 1984.

Aula. Tradução de Leyla Perrone-Moisés. São Paulo: Cultrix, 1980.

BIBLIOBS. Christine Angot condamnée à verser 40.000 euros à Elise Bidoit. Disponível em: $\quad$ https://bibliobs.nouvelobs.com/actualites/20130527.OBS0830/christine-angotcondamnee-a-verser-40-000-euros-a-elise-bidoit.html>. Acesso em: 03 jul. 2019.

BRASIL. Constituição Federal. Disponível em: <http://www.planalto.gov.br/ccivil_03/constituicao/constituicao.htm>. Acesso em: 03 jul. 2019. 

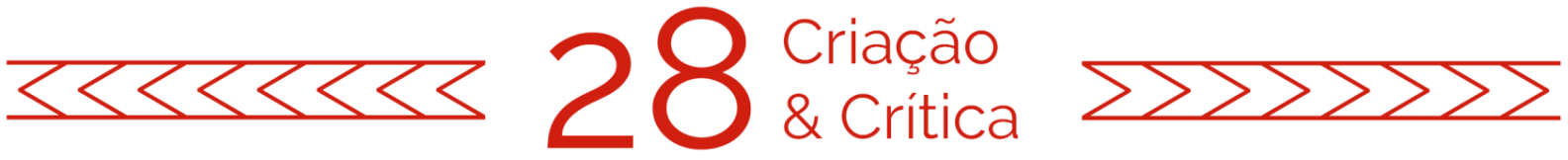

BRASIL, L. A. A. Escrever ficção: um manual de criação literária. São Paulo: Companhia das Letras, 2019.

CALVINO, I. Se um viajante numa noite de inverno. São Paulo: Companhia das Letras, 2002.

ÉPOCA., autor transforma sua história em livro e peça teatral. Disponível em: $<$ https://epoca.globo.com/vida/noticia/2016/05/acusado-de-falsificar-documento-autortransforma-sua-historia-em-livro-e-peca-teatral.html>. Acesso em: 03 jul. 2019.

FREITAS, D. S. Slam Resistência: poesia, cidadania e insurgência. Estudos de Literatura Brasileira Contemporânea, Brasília, nํ59, 2020.

KING, S. Sobre a escrita: a arte em memórias. Tradução de Michel Teixeira. Rio de Janeiro: Objetiva, 2015.

LIPOVETSKY, G. L'ère du vide: Essais sur l'individualisme contemporain. Paris: Gallimard, 1989. Edição Kindle.

PALLOTTINI, R. Dramaturgia: A construção do personagem. São Paulo: Editora Ática, 1989.

PERRONE-MOISÉS, L. Mutações da literatura no século XXI. São Paulo: Companhia das Letras, 2016.

PETIT, M. A arte de ler ou como resistir à adversidade. São Paulo: Editora 34, 2009.

PIGLIA, R. O último leitor. Tradução de Heloisa Jahn. São Paulo: Companhia das Letras, 2006.

SALLES, C. A. Gesto inacabado: processo de criação artística. São Paulo: FAPESP/Annablume, 1998.

SOMERS-WILLET, S. B. The cultural politics of slam poetry: race, identity and the performance of popular verse in America. Ann Arbor: University of Michigan Press, 2009.

SOUZA, R. T. Ética do escrever: Kafka, Derrida e Literatura como crítica da violência. Porto Alegre, RS: Zouk, 2018.

ZUMTHOR, P. Performance, recepção, leitura. São Paulo, Cosac \& Naify, 2014.

Recebido em: 23/07/2020

Aceito em: $23 / 11 / 2020$

Referência eletrônica: RICHINITTI, Gabriela. Literatura: o potencial humanizador da mais solitária das artes. Criação \& Crítica, n. 28, p., dez. 2020. Disponível em: <http://revistas.usp.br/criacaoecritica>. Acesso em: dd mmm. aaaa. 